\title{
KEAKURATAN KODE DIAGNOSIS HEPATITIS BERDASARKAN ICD-10 PASIEN RAWAT INAP DI RUMAH SAKIT LANCANG KUNING PEKANBARU
}

\author{
Tri Purnama Sari ${ }^{1}$, Nurul Husna Dewi ${ }^{2}$ \\ STIKes Hang Tuah Pekanbaru \\ tripurnamasariayi@gmail.com
}

\begin{abstract}
Activities and actions as well as the diagnosis in medical record should be coded and subsequently will be indexed in order to facilitate the presentation of information services to support the planning, management, and research in health. In this regard, this research employs quantitative method with a qualitative approach that aimed to determine the accuracy code of Hepatitis diagnosis based on ICD-10 at Hospital Lancang Kuning Pekanbaru. The result of this research shows that the accuracy codes of Hepatitis diagnosis at Hospital Pekanbaru Lancang Kuning can not be said to be good because there are many discovery of an inaccurate diagnosis codes which 29 of the 90 samples were inaccurate with a percentage of $32.2 \%$ and 61 files were accurate from 90 samples with a percentage of 77.8\%. Standard Operating Procedures (SOP) at Hospital Lancang Kuning Pekanbaru have been executed by officers in accordance with the procedure remains in the hospital and Human Resources (HR) at the hospital Lancang Kuning Pekanbaru is good. it can be seen in terms of educational backgrounds D3 Medical Record the officer but they had never attended training on coding properly.
\end{abstract}

Keywords: Accuracy, ICD-10 codes, and Diagnosis Hepatitis

\begin{abstract}
Abstrak
Kegiatan dan tindakan serta diagnosa yang ada didalam rekam medis harus diberi kode dan selanjutnya di indeks agar memudahkan pelayanan pada penyajian informasi untuk menunjang fungsi perencanaan, manajemen, dan riset bidang kesehatan. Metode penelitian yang digunakan adalah gabungan kuantitatif - kualitatif. Tujuan penelitian $n$ untuk mengetahui jumlah keakuratan kode diagnosis Hepatitis berdasarkan ICD-10 di Rumah Sakit Lancang Kuning Pekanbaru. Hasil penelitian diperoleh bahwa keakuratan kode diagnosis Hepatitis belum dapat dikatakan baik karena masih banyak ditemukannya kode diagnosis yang tidak akurat yaitu 29 $(32,2 \%)$ dan 61(77,8\%) berkas yang akurat. Standar Prosedur Operasional (SPO) di rumah Sakit Lancang Kuning Pekanbaru sudah dijalankan oleh petugas sesuai dengan dengan prosedur tetap di rumah sakit dan Sumber Daya Manusia (SDM) di rumah sakit Lancang Kuning Pekanbaru sudah baik hal ini dilihat dari segi pendidikan yang berlatar belakang D3 Rekam Medis akan tetapi petugas belum pernah mengikuti pelatihan tentang pengkodingan yang baik dan benar.
\end{abstract}

Kata Kunci: Keakuratan, Kode ICD-10, dan Diagnosa Hepatitis.

\section{PENDAHULUAN}

Pembangunan kesehatan adalah bagian terpadu dari pembangunan sumber daya manusia dalam mewujudkan bangsa yang maju dan mandiri serta sejahtera lahir dan batin. Salah satu ciri bangsa yang maju adalah bangsa yang mempunyai derajat kesehatan yang tinggi (Adisasmito, 2010:4).
Sistem Kesehatan Nasional adalah bentuk dan cara penyelenggaraan pembangunan yang memadukan berbagai upaya bangsa Indonesia dalam satu derap langkah guna menjamin tercapainya tujuan pembangunan kesehatan dalam kerangka mewujudkan kesejahteraan rakyat sebagaimana dimaksud dalam Undang-Undang Dasar 1945. Untuk 
dapat mencapai derajat kesehatan yang optimal dan setinggi-tingginya perlu diadakan berbagai upaya kesehatan dengan menghimpun seluruh potensi bangsa Indonesia. Upaya kesehatan diupayakan dengan upaya peningkatan, pencegahan, pengobatan ,dan pemulihan (DepKes RI, 2009:2).

Rumah sakit adalah suatu institusi pelayanan kesehatan yang kompleks, padat pakar dan padat modal. Kompleksitas ini muncul karena pelayanan rumah sakit menyangkut berbagai fungsi pelayanan, pendidikan dan penelitian serta mencakup berbagai tingkatan maupun jenis disiplin, agar rumah sakit mampu melaksanakan fungsi yang professional baik dibidang teknis medis maupun administrasi kesehatan. Untuk menjaga dan meningkatkan mutu rumah sakit harus mempunyai suatu ukuran yang menjamin peningkatan mutu disemua tingkatan (Rustiyanto, 2009:37).

Untuk melaksanakan pelayanan di rumah sakit diperlukan suatu bagian yang penting, yaitu rekam medis. Rumah sakit yang berkualitas, mampu menyajikan informasi yang lengkap tentang proses pelayanan medis dan kesehatan di rumah sakit tersebut. Oleh karna itu semua petugas di rumah sakit baik tenaga medis, pramedis, maupun tenaga non medis harus menyelenggarakan pelayanan yang bermutu dan sesuai dengan standar yang telah ditetapkan melalui Keputusan Mentri Kesehatan No. 436/Menkes/VI/1993 (Depkes, 2006:11).

Rekam Medis adalah keterangan baik yang tertulis maupun yang terekam tentang identitas, anamnese, pemeriksaan fisik, laboratorium, diagnose serta pelayanan dan tindakan medis yang diberikan kepada pasien, dan pengobatan baik yang dirawat inap, rawat jalan maupun yang mendapatkan pelayanan gawat darurat (DepKes RI,2006: 11).

Penetapan Diagnosa seorang pasien merupakan kewajiban, hak dan tanggung jawab dokter (tenaga medis) yang terkait tidak boleh diubah oleh karenanya harus diagnosis yang ada dalam rekam medis diisi dengan lengkap dan jelas sesuai dengan arahan yang ada pada buku ICD-10. Tenaga medis sebagai seorang pemberi kode dari suatu diagnosis yang sudah ditetapkan oleh tenaga medis (DepKes RI, 2006:60).

Hepatitis dapat diartikan secara sederhana, yaitu peradangan pada hati. Peradangan hati bisa dikarnakan infeksi oleh virus, bakteri maupun parasit. Yang kita bicarakan disini adalah infeksi jaringan hati karena virus. Jenis hepatitis inilah yang paling berbahaya. Hepatitis karena virus ada beberapa jenis meskipun gejala klinik boleh dikatakan sama. Perbedaan berdasarkan imunologi, epidemiologi, dan beberapa gejala yang khas pada masing-masing jenis virus, yakni Hepatitis A, B, C, D dan E. (DR. Faisal Yatim, 2004:51)

Pemberian Kode adalah pemberian penetapan kode dengan menggunakan huruf atau angka dan kombinasi huruf dalam angka yang mewakili komponen data. Kegiatan dan tindakan serta diagnosa yang ada didalam rekam medis harus diberi kode dan selanjutnya di indeks agar memudahkan pelayanan pada penyajian informasi untuk menunjang fungsi perencanaan, manajemen, dan riset bidang kesehatan (DepKes RI, 2006: 59).

ICD-10 adalah klasifikasi statistik, yang berarti bahwa ICD-10 berisi nomor-nomor terbatas dari katagori kode eksklusif yang menggambarkan seluruh konsep penyakit. Klasifikasi mempunyai struktur hirarki dengan subdivisi-subdivisi untuk mengidentifikasi kelompok besar dan sesuatu yang spesifik (DepKes, 1999). Koding menurut WHO (DepKes RI, 1999) adalah penetapan sandi atau penentuan penggunaan nomor, huruf atau kombinasi huruf angka untuk mewakili komponen data terkait. Koding diagnosis harus dilaksanakan sesuai aturan system koding ICD-10 akurat dan tepat waktu.

Tujuan ICD-10 diantaranya adalah untuk mendapatkan rekaman sistematis, melakukan analisis, interprestasi serta membandingkan data morbiditas dari negara yang berbeda atau antara wilayah pada waktu yang berbeda, untuk menerjemahkan diagnosis penyakit dan masalah kesehatan dari kata-kata menjadi kode alfa numerik yang akan memudahkan penyimpanan, mendapatkan data kembali dan analisis data, memudahkan entry data ke data base komputer yang tersedia, menyediakan data yang diperlukan oleh system pembayaran atau penagihan biaya yang dijalankan, memaparkan indikasi alasan mengapa pasien memperoleh asuhan atau perawatan atau pelayanan, dan menyediakan informasi diagnosis dan tindakan bagi riset, edukasi dan kajian assement kualitas keluaran.

Rumah Sakit Lancang Kuning Pekanbaru adalah Rumah Sakit Swasta yang terletak dikota Pekanbaru beralamatkan di jalan Ronggowarsito Ujung no. 5a Pekanbaru Riau. Rumah Sakit Lancang Kuning adalah rumah sakit swasta tipe D. Rumah sakit ini bersifat transisi dengan standar SPO, akan tetapi masih ditemukannya kekurangan atau ketidaktepatan 
dalam pemberian kode terhadap diagnosa yang telah ditulis oleh dokter.

Berdasarkan hasil observasi awal di Rumah Sakit Lancang Kuning Pekanbaru terdapat 8 berkas yang tidak akurat, yaitu bebagai berikut:

Tabel 1 Ketidakakuratan Kode Diagnosa Hepatitis di Rumah Sakit Lancang Kuning Pekanbaru

\begin{tabular}{llllll}
\hline No & No RM & $\begin{array}{l}\text { Diagnosa } \\
\text { Kode }\end{array}$ & $\begin{array}{l}\text { Kode Se- } \\
\text { harusnya }\end{array}$ & $\begin{array}{l}\text { Kete- } \\
\text { rangan }\end{array}$ \\
\hline 1 & 110300 & $\begin{array}{l}\text { Chronic } \\
\text { hepatic } \\
\text { failure }\end{array}$ & $\mathrm{K} 72$ & $\mathrm{~K} 72.1$ & $\begin{array}{l}\text { Tidak } \\
\text { akurat }\end{array}$ \\
\hline 2 & 002352 & $\begin{array}{l}\text { Hepatic } \\
\text { fibrosis }\end{array}$ & - & $\mathrm{K} 74.0$ & $\begin{array}{l}\text { Tidak } \\
\text { akurat }\end{array}$ \\
\hline 3 & 072201 & $\begin{array}{l}\text { Alcholic } \\
\text { Hepatitis }\end{array}$ & - & $\mathrm{K} 70.1$ & $\begin{array}{l}\text { Tidak } \\
\text { akurat }\end{array}$ \\
\hline 4 & 159283 & $\begin{array}{l}\text { Abcess of } \\
\text { liver }\end{array}$ & - & $\mathrm{K} 75.0$ & $\begin{array}{l}\text { Tidak } \\
\text { akurat }\end{array}$ \\
\hline 5 & 067789 & $\begin{array}{l}\text { Hepatic } \\
\text { sclerosis }\end{array}$ & $\mathrm{K} 35$ & $\mathrm{~K} 74.1$ & $\begin{array}{l}\text { Tidak } \\
\text { akurat }\end{array}$ \\
\hline 6 & 005378 & $\begin{array}{l}\text { Hepatic } \\
\text { failure }\end{array}$ & $\mathrm{K} 73$ & $\mathrm{~K} 72.9$ & $\begin{array}{l}\text { Tidak } \\
\text { akurat }\end{array}$ \\
\hline 7 & 107035 & $\begin{array}{l}\text { Infraction } \\
\text { ofliver }\end{array}$ & $\mathrm{K} 76$ & $\mathrm{~K} 76.3$ & $\begin{array}{l}\text { Tidak } \\
\text { akurat }\end{array}$ \\
\hline 8 & 111234 & $\begin{array}{l}\text { Portal } \\
\text { Hyperten- } \\
\text { sion }\end{array}$ & $\mathrm{K} 76$ & $\mathrm{~K} 76.6$ & $\begin{array}{l}\text { Tidak } \\
\text { akurat }\end{array}$ \\
\hline
\end{tabular}

Berdasarkan hasil survei awal di Rumah Sakit Lancang Kuning Pekanbaru dengan mengambil 8 sampel berkas rekam medis dengan kasus hepatitis ditemukan 3 berkas tidak dikode dan 5 berkas tidak tepat kodenya. Hal ini mengingat pengkodean penyakit sangat penting dan perlu dilakukan. Bila pengkodean diagnosis penyakit yang dilakukan ditulis tidak benar dan tidak lengkap bahkan tidak ditulis (terdapat kekosongan) maka dapat menyebabkan kesulitan dalam pembuatan laporan dan penyajian data statistik rumah sakit yaitu laporan internal dan laporan eksternal.

\section{METODE PENELITIAN}

Penelitian ini menggunakan metode kuantitatif dengan pendekatan kualitatif. Populasi dalam penelitian ini sejumlah 115 berkas Rekam Medis Pasien Rawat Inap di Rumah Sakit Lancang Kuning Pekanbaru. Besar sampel dalam penelitian ini adalah 90 sampel yang diambil dengan teknik Sistematic Random Sampling. Adapun yang menjadi informan pada penelitian ini yaitu Kepala Rekam Medis dan staf dibagian koding di Rumah Sakit Lancang Kuning Pekanbaru.
Tabel 2 Informan Penelitian

\begin{tabular}{lllll}
\hline No & $\begin{array}{l}\text { Informan } \\
\text { Penelitian }\end{array}$ & $\begin{array}{l}\text { Pendidi- } \\
\text { kan }\end{array}$ & $\begin{array}{l}\text { Masa } \\
\text { Kerja }\end{array}$ & Kode \\
\hline & $\begin{array}{l}\text { Kepala Re- } \\
\text { kam Medis }\end{array}$ & SMA & 16 Thn & 1 \\
& $\begin{array}{l}\text { Petugas Ko- } \\
\text { ding (koder) }\end{array}$ & $\begin{array}{l}\text { D3 Rekam } \\
\text { Medis }\end{array}$ & 3 Thn & 2 \\
\hline & & & 2 orang \\
\hline
\end{tabular}

\section{HASIL}

\section{Hasil Observasi}

Berdasarkan hasil observasi keakuratan kode diagnosis Hepatitis pada pasien rawat inap di rumah sakit Lancang Kuning Pekanbaru tingkat keakuratan kode diagnosis Hepatitis dapat dilihat pada tabel berikut:

Tabel 3. Keakuratan Kode Diagnosis Hepatitis

\begin{tabular}{ccc}
\hline $\begin{array}{c}\text { Keakuratan } \\
\text { Kode }\end{array}$ & Frekuensi & Persentase \\
\hline Tidak Akurat & 29 & 32.2 \\
Akurat & 61 & 67.8 \\
\hline Total & 90 & 100 \\
\hline
\end{tabular}

Dari tabel 3 diketahui bahwa kode diagnosis yang akurat sebanyak 61 kode diagnosis dengan persentase $67,8 \%$ dan kode diagnosis yang tidak akurat sebanyak 29 kode diagnosis dengan persentase $32,2 \%$ dari 90 berkas rekam medis.

\section{Hasil Wawancara}

Informan penelitian terdiri dari dua orang mengenai diagnosa Hepatitis di Rumah Sakit Lancang Kuning Pekanbaru

Dari tabel 2 dijelaskan bahwa informan dalam penelitian ini adalah satu orang Kepala Rekam Medis yang berpendidikan SMA dengan masa kerja 16 tahun di Rumah Sakit Lancang Kuning Pekanbaru dan diberi kode informan "1". Dan satu orang petugas koding yang berpendidikan D3 Rekam Medis dengan masa kerja 3 tahun di Rumah Sakit Lancang Kuning Pekanbaru dan diberi kode informan "2".

\section{Sumber Daya Manusia (SDM) dibagian Koding Rumah Sakit Lancang Kuning Pekanbaru}

Berdasarkan hasil wawancara tentang bagaimana sumber daya manusia dibagian koding Rumah Sakit Lancang Kuning Pekanbaru mengatakan bahwa: 


\begin{abstract}
"Rumah Sakit Lancang Kuning masih memerlukan tambahan karyawan khususnya petugas dibagian koding untuk mengingat pentingnya pengkodingan yang benar, Rumah Sakit Lancang Kuning hanya memiliki satu petugas koding dan itu pun tidak bisa dilepaskan mengkoding diagnosa sendiri perlu didampingi oleh kepala rekam medis. Ditambah lagi petugas koding sama sekali belum pernah mengikuti pelatihan tentang pengkodingan yang baik dan benar"( informan 1).
\end{abstract}

"Rumah Sakit Lancang Kuning perlu adanya penambahan karyawan dibagian koding, abang sendiri mengkoding sedangkan berkas yang mau dikoding banyak jadi abang kewalahan makanya kadang sering salah-salah kodenya" (informan 2).

Dari hasil wawancara terhadap kedua informan diatas dapat diketahui bahwa petugas dibagian koding sama sekali belum pernah mengikuti pelatihan tentang rekam medis khusunya pelatihan tentang pengkodingan yang baik dan benar ditambah lagi kurangnya tenaga dibagian koding membuat proses pengkodingan di Rumah Sakit Lancang Kuning Pekanbaru belum maksimal berjalan dengan baik dan maksimal.

\section{Standar Prosedur Operasional (SPO) dibagian koding di Rumah Sakit Lancang Kuning Pekan- baru Tahun 2015}

Berdasarkan hasil wawancara mengenai Standar Prosedur Operasional (SPO) dibagian koding Rumah Sakit Lancang Kuning Pekanbaru mengatakan bahwa :

"Saya sudah selalu memberitahu kepada karyawan agar bekerja sesuai SPO yang sudah ditetapkan oleh pihak rumah sakit, menurut saya petugas sudah bekerja sesuai SPO yang sudah ditetapkan oleh pihak rumah sakit" (Informan 1).

"Petugas sudah melaksanakan pengkodingan sesuai dengan SPO yang berlaku (Informan 2)".

Dari hasil wawancara terhadap kedua informan diatas dapat diketahui bahwa Standar Prosedur Operasional sudah dibuat dan ditetapkan oleh pihak Rumah Sakit Lancang Kuning Pekanbaru dan petugas juga sudah melaksanakan pengkodingan sesuai dengan SPO yang sudah ditetapkan oleh pihak Rumah Sakit Lancang Kuning Pekanbaru.

\section{PEMBAHASAN}

Keakuratan Kode Diagnosis Hepatitis Berdasarkan ICD-10 Pasien Rawat Inap Rumah Sakit Lancang Kuning Pekanbaru

Berdasarkan hasil penelitian dari 90 berkas rekam medis pasien rawat inap yang menjadi sampel di Rumah Sakit Lancang Kuning Pekanbaru bulan Januari s/d April Tahun 2015. Kode diagnosa yang akurat sebanyak 61 berkas rekam medis dengan persentase $67,8 \%$, sedangkan yang tidak akurat sebanyak 29 berkas rekam medis dengan persentase $32,2 \%$.

Untuk menentukan kualitas pengkodingan diagnosa tersebut termasuk level yang baik, atau cukup, atau kurang baik, atau tidak baik. Rentang nilai tersebut ditentukan dengan menggunakan (Arikunto, 1992) yaitu sebagai berikut:

Tabel 5 Rentang Nilai Kualitas Pengisian Data

\begin{tabular}{cc}
\hline Kriteria & Rentang Nilai \\
\hline Baik & $78-100$ \\
\hline Cukup & $56-75$ \\
\hline Kurang baik & $40-55$ \\
\hline Tidak baik & $0-39$ \\
\hline
\end{tabular}

Sumber: Buku Prosedur Penelitian Oleh Arikunto Tahun 1992

Jumlah kode diagnosis Hepatitis yang akurat sebanyak 61 berkas dengan persentase $67,8 \%$ termasuk katagori cukup dan jumlah kode yang tidak akurat sebanyak 29 berkas dengan persentase $32,2 \%$ termasuk katagori tidak baik berdasarkan tabel 4.3 diatas oleh Arikunto Tahun 1992.

Menurut (Hatta, 2008: 154), Standar dan etika pengkodean (coding) yang dikembangkan AHIMA, meliputi beberapa standar yang harus dipenuhi oleh coder professional, antara lain:

a. Pengkode harus mengikuti sistem klasifikasi yang sedang berlaku dengan memilih pengkodean diagnosis dan tindakan yang tepat.

b. Akurat, komplet dan konsisten untuk menghasilkan data yang berkualitas.

c. Pengkode harus ditandai dengan laporan kode yang jelas dan konsisten pada dokumentasi dokter dalam rekam medis pasien.

d. Pengkode professional harus berkonsultasi dengan dokter untuk klasifikasi dan kelengkapan pengisian data diagnosis dan tindakan.

e. Pengkode professional tidak mengganti kode pada bill pembayaran. 
f. Pengkode professional harus mengembangkan kebijakan pengkodean di institusinya.

g. Pengkode professional harus secara rutin meningkatkan kemampuannya dibidang pengkodean.

h. Pengkode professional senantiasa berusaha untuk memberi kode yang paling sesuai untuk pembayaran.

Penulis berpendapat bahwa keakuratan kode diagnosis Hepatitis di Rumah Sakit Lancang Kuning Pekanbaru belum bisa dikatakan baik, karena masih banyak ditemukannya kode diagnosis yang tidak tepat. Hal ini sejalan dengan teori yang dikemukakan oleh Hatta (2008) bahwa pengkodingan harus akurat, komplet dan konsisten agar menghasilkan kode diagnosis yang tepat dan akurat.

\section{Sumber Daya Manusia (SDM) Rekam Medis dibagian Koding Rumah Sakit Lancang Kuning Pekanbaru Tahun 2015}

Berdasarkan hasil penelitian dibagian koding Rumah Sakit Lancang Kuning Pekanbaru hanya ada satu orang petugas dibagian koding dan berlatar belakang D3 Rekam Medis dan belum pernah mengikuti pelatihan tentang pengkodingan yang baik dan benar sesuai ICD-10.

Kualitas sumber daya manusia sebuah bangsa ditentukan oleh tiga faktor utama, yakni pendidikan, kesehatan, dan ekonomi. Oleh karena itu apabila kita menilai kualitas sumber daya manusia sebuah bangsa dapat diukur dari tingkat pendidikan, kesehatan dan ekonomi dari bangsa yang bersangkutan (Notoatmodjo, 2009).

Pendidikan dan pelatihan dapat dipandang sebagai salah satu bentuk investasi. Oleh karna itu setiap organisasi atau institusi yang ingin berkembang, maka pendidikan dan pelatihan bagi karyawannya harus memperoleh perhatian yang besar. Pentingnya program pendidikan dan pelatihan bagi suatu institusi antara lain sebagai berikut:

a. Sumber daya manusia atau karyawan yang menduduki suatu jabatan tertentu dalam organisasi, belum tentu mempunyai kemampuan yang sesuai dengan persyaratan yang diperlukan dalam jabatan tersebut. Oleh sebab itu karyawan perlu penambahan kemampuan yang mereka perlukan.

b. Dengan adanya kemajuan ilmu dan teknologi, jelas akan mempengaruhi suatu organisasi. Oleh sebab itu jabatan-jabatan yang dulu belum diperlukan, sekarang dipelukan. Kemapuan orang yang akan menepati jabatan tersebut terkadang tidak ada. Dengan demikian maka perlu penambahan atau peningkatan kemampuan yang diperlukan oleh jabatan tersebut.

c. Promosi dalam suatu organisasi adalah suatu keharusan, apabila organisasi itu mau berkembang. Pentingnya promosi bagi seseorang adalah sebagai salah satu reward dan insentive. Kadang-kadang kemapuan seorang karyawan yang akan dipromosikan untuk menduduki jabatan tertentu belun belum tentu cukup. Oleh karna itulah diperlukan pelatihan tambahan.

d. Pentingnya pelatihan seperti diuraikan diatas, bukanlah semata-mata bagi karyawannya atau pegawai yang bersangkutan, tetapi juga keuntungan bagi organisasi. Karena dengan meningkatkan kemampuan atau keterampilan para karyawan, dapat meningkatkan produktivitas kerja para karyawan. Produktivitas kerja para karyawan meningkat, berarti organisasi yang bersangkutan akan memperoleh keuntungan, (Notoatmodjo, 2003: 30).

Penulis berpendapat bahwa kualitas sumber daya manusia dibagian pengkodingan sudah baik. Dilihat dari segi pendidikan dengan latar belakang pendidikan D3 Rekam Medis, namun sumber daya manusia dibagian koding masih kurang. Namun SDM dibagian koding belum pernah mengikuti, oleh sebab itu pengkodingan masih terdapat ketidakakuratan kode. Hal ini sejalan dengan teori yang dikemukakan oleh Notoatmodjo (2003) bahwa penelitian mempunyai peranan penting dalam meningkatkan kemampuan SDM.

\section{Standar Prosedur Operasional (SPO) dibagian Koding Rumah Sakit Lancang Kuning Pekan- baru Tahun 2015}

Berdasarkan hasil penelitian dapat diketahui bahwa mengenai Standar Prosedur Operasional (SPO) bagian koding sudah dijalankan oleh petugas sesuai dengan prosedur tetap di rumah sakit. Hal tersebut dapat diketahui dari penulisan kode penyakit dan penulisan kode tindakan medik atau operasi didalam kotak yang tersedia pada lembar formulir ringkasan masuk dan keluar. Namun masih ada ditemukan beberapa berkas rekam medis yang tidak diassembling dan masih ada ditemukan data penyakit tidak jelas atau belum ditulis oleh dokter. 
a. Peran dan Manfaat Standar Prosedur Operasional (SPO)

1) Menjadi pedoman kebijakan yang merupakan dasar bagi seluruh kegiatan organisasi, secara operasional maupun administratif. (Pedoman Kebijakan).

2) Menjadi pedoman kegiatan-kegiatan organisasi, baik secara operasional maupun administratif (Pedoman Kegiatan).

3) Menjadi pedoman untuk memvalidasi langkah-langkah kegiatan dalam organisasi (Pedoman Birokrasi).

4) Menjadi pedoman terkait penggunaan formulir, dokumen, blanko, dan laporan yang digunakan dalam kegiatan-kegiatan organisai. (Pedoman Administrasi).

5) Menjadi pedoman penilaian efektifitas kegiatan organisasi. (Pedoman Evaluasi Kinerja).

6) Menjadi pedoman mengintegrasikan kegiatan-kegiatan organisasi, untuk membantu mencapai tujuan organisasi, (Pedoman Integrasi).

b. Keuntungan Standar Prosedur Operasional (SPO)

1) SPO yang baik akan menjadi pedoman bagi pelaksana, menjadi alat komunikasi, pengawasan dan menjadi pekerjaan yang diselesaikan secara konsisten.

2) Tahu apa yang harus dicapai dalam setiap pekerjaan.

3) SPO juga bisa dipergunakan sebagai salah satu alat training dan bisa digunakan untuk mengukur kinerja pegawai (Tambunan,2013:86).

Penulis berpendapat bahwa Standar Prosedur Operasional (SPO) dirumah sakit Lancang Kuning Pekanbaru sudah memiliki SPO dan sudah terlaksana dengan baik. Hal ini sejalam dengan teori yang ada, bahwa kegunanan SPO merupakan pedoman dalam kegiatan pengkodingan. Oleh sebab itu pengkodingan penyakit di Rumah Sakit Lancang Kuning Pekanbaru masih terdapat ketidakakuratan.

\section{SIMPULAN}

Dari 90 sampel rekam medis pasien rawat inap di Rumah Sakit Lancang Kuning Pekanbaru didapat kode diagnosis yang akurat sebanyak 61 sampel rekam medis dengan persentase $67,8 \%$, sedangkan kode diagnosis yang tidak akurat sebanyak 29 sampel rekam medis dengan persentase $32,2 \%$.

Sumber Daya Manusia (SDM) dibagian koding Rumah Sakit Lancang Kuning Pekanbaru sudah dapat dikatakan baik dikarenakan petugas koding merupakan berlatar belakang D3 Rekam Medis akan tetapi belum pernah mengikuti pelatihan tentang pengkodingan.

Standar Prosedur Operasional (SPO) pengkodingan diagnosa penyakit di Rumah Sakit Lancang Kuning Pekanbaru sudah dibuat oleh pihak Rumah Sakit dan petugas sudah melakukan sesuai dengan prosedur tetap dari Rumah Sakit.

\section{DAFTAR PUSTAKA}

Adisasmito, W. (2008). Sistem Kesehatan. Jakarta: PT Raja Grafindo Persada.

DepKes RI. (2006) Pedoman Penyelenggaraan dan Prosedur Rekam Medis Rumah Sakit di Indonesia, Jakarta: Direktorat Jendral Pelayanan Medik.

(2009) Sistem Kesehatan Nasional. Jakarta.

Fathoni, A. (2006). Manajemen Sumber Daya Manusia. Jakarta: Rineka Cipta.

Hatta, G.R. (2008). Pedoman Manajemen Informasi Kesehatan di Sarana Pelayanan Kesehatan. Jakarta: UI-Press

Indriyani. (2013). DepKes 2004 Tenaga kesehatan. Pekanbaru. 
Tri Purnama Sari dan Nurul Husna Dewi. Kakuratan Kode Diagnosis Hepatitis Berdasarkan ...

Notoatmodjo. (2003). Pengembangan Sumber Daya Manusia. Jakarta: Rieneka Cipta.

(2005). Metodologi Penelitian Kesehatan. Jakarta: Rinaeka Cipta.

(2009). Pengembangan Sumber Daya Manusia. Jakarta: Rinaeka Cipta.

(2010). Metodologi Penelitian Kesehatan. Jakarta: Rinaeka Cipta.

Rahayu. W.A. (2013). Kode Klasifikasi Penyakit Dan Tindakan Medis ICD-10. Yogyakarta: Gosyen Publishing.
Rustiyanto, E. (2009). Etika Profesi Perekam Medis dan Informasi Kesehatan. Yogyakarta : Graha Ilmu.

Tambunan. R. (2013). Standar Operating Prosedure (SOP). Jakarta: Maiestas Publising.

Yatim, F. (2004). Macam-macam Penyakit Menular dan Pencegahannya. Jakarta: Pustaka Populer Obor.

Undang-Undang Republik Indonesia No. 44 tahun 2009, Tentang Rumah Sakit. 